\title{
IDENTIFIKASI AUTOKORELASI SPASIAL PADA KASUS MALARIA DI PROVINSI ACEH MENGGUNAKAN KOEFISIEN GEARY
}

\author{
MEILINA DINIARI, HAZMIRA YOZZA, FERRA YANUAR \\ Program Studi S1 Matematika, \\ Fakultas Matematika dan Ilmu Pengetahuan Alam, Universitas Andalas, \\ Kampus UNAND Limau Manis Padang, Indonesia. \\ email : diniarimeilina@gmail.com,hazmirayozza@sci.unand.ac.id,ferrayanuar@sci.unand.ac.id
}

Diterima 16 Juni 2020 Direvisi 22 Juni 2020 Dipublikasikan 13 Juli 2020

\begin{abstract}
Abstrak. Malaria adalah penyakit yang disebabkan oleh parasit Plasmodium sp yang disebarkan oleh nyamuk Anopheles betina. Banyaknya penduduk suatu daerah yang terjangkit penyakit malaria akan berpengaruh terhadap banyaknya penduduk di daerah sekitarnya yang terjangkit penyakit tersebut. Hal ini disebabkan karena nyamuk yang terinfeksi parasit dapat berpindah dari suatu daerah ke daerah lain dan menyebarkan parasit malaria ke daerah tersebut. Untuk mengetahui hubungan antar wilayah digunakan koefisien Geary. Pada kasus malaria di Provinsi Aceh diperoleh $c=0,513794945$. Nilai $c<1$ menyatakan bahwa pada data kasus malaria terdapat autokorelasi positif yang berarti wilayah yang saling berdekatan memiliki nilai yang mirip, sehingga dapat disimpulkan bahwa terdapat autokorelasi spasial pada data kasus malaria di Provinsi Aceh.

Kata Kunci: Malaria, Koefisien Geary's, Autokorelasi
\end{abstract}

\section{Pendahuluan}

Malaria adalah penyakit yang disebabkan oleh parasit Plasmodium sp yang disebarkan oleh nyamuk Anopheles betina. Nyamuk yang terinfeksi parasit dapat berpindah dari suatu daerah ke daerah lain dan menyebarkan parasit malaria ke daerah tersebut. Dengan demikian, dapat diduga banyaknya penduduk suatu daerah yang terjangkit penyakit malaria akan berpengaruh terhadap banyaknya penduduk di daerah-daerah yang berdekatan yang terjangkit penyakit tersebut. Oleh karena itu dapat dikatakan bahwa data penyebaran malaria ini dapat dikategorikan sebagai data spasial.

Untuk mengetahui hubungan antar wilayah, perlu dilakukan uji autokorelasi spasial. Untuk data kasus malaria di Provinsi Aceh pada penelitian ini digunakan koefisien Geary.

*penulis korespondensi 


\section{Landasan Teori}

\subsection{Data Spasial}

Analisis data spasial merupakan suatu analisis data untuk mendapatkan informasi pengamatan yang dipengaruhi efek ruang atau lokasi. Pengaruh efek ruang tersebut disajikan dalam bentuk koordinat lokasi (longitude, latitude) atau pembobotan. Metode ini banyak digunakan untuk analisis geostatistik maupun pemodelan matematika yang membutuhkan adanya informasi lokasi [1].

\subsection{Matriks Pembobot Spasial}

Matriks pembobot spasial $\mathbf{W}$ merupakan matriks berukuran $n \times n$ yang menggambarkan hubungan kedekatan antar wilayah pengamatan [4]. Matriks ini dibentuk dari matriks contiguity $\mathbf{C}$ yang menunjukkan ketetanggaan dari wilayah pengamatan tersebut. Elemen matriks $\mathbf{C}, c_{i j}=0$ jika wilayah $i$ dan $j$ tidak bertetangga dan elemen $c_{i j}=1$ jika wilayah $i$ dan $j$ bertetangga. Terdapat tiga tipe matriks contiguity dalam menentuka ketetanggaan antar wilayah, yaitu

(1) Rook Contiguity

Ketetanggaan dengan Rook contiguity dipandang dari persentuhan sisi wilayah satu dengan sisi wilayah yang lain yang bertetangga (side) [5].

(2) Bishop Contiguity

Dengan metode Bishop contiguity ketetanggaan dipandang dari persentuhan antar sudut wilayah satu dengan wilayah lain yang bertetangga (vertex) [5].

(3) Queen Contiguity

Matriks ketetanggaan dengan metode Queen contiguity dilihat dari persentuhan sisi (side) ataupun titik sudut (vertex) wilayah satu dengan wilayah yang lain $[5]$.

Untuk membentuk matriks pembobot spasial dapat dilakukan dengan membentuk matriks contiguity menjadi matriks normalitas dengan rumus [5]:

$$
w_{i j}=\frac{c_{i j}}{\sum_{j=1}^{n} c_{i j}}
$$

dengan $w_{i j}$ adalah elemen dari matriks pembobot spasial.

\subsection{Koefisien Geary's dan Pengujiannya}

Salah satu metode untuk mengukur autokorelasi spasial adalah Geary's c [6]. Perhitungan autokorelasi spasial menggunakan Geary's c adalah

$$
c=\frac{(n-1) \sum_{i=1}^{n} \sum_{j=1}^{n} w_{i j}\left(Y_{i}-Y_{j}\right)^{2}}{2\left(\sum_{i=1}^{n}\left(Y_{i}-\bar{Y}\right)^{2}\right)\left(\sum_{i=1}^{n} \sum_{j=1}^{n} w_{i j}\right)}
$$

Koefisien Geary c mempunyai nilai di antara 0 dan 2. Jika tidak ada hubungan spasial, diperoleh nilai $c=1$. Nilai $c<1$ menyatakan autokorelasi positif yang 
berarti wilayah berdekatan memiliki nilai yang mirip. Jika nilai $c>1$, menyatakan autokorelasi negatif yang berarti wilayah berdekatan memiliki nilai berbeda. Menurut [4] nilai harapan dari c adalah $E(c)=1$ dengan varians sebagai berikut.

$$
\operatorname{Var}(c)=\frac{\left(2 S_{1}+S_{2}\right)(n-1)-4 S_{0}^{2}}{2(n+1) S_{0}^{2}}
$$

dengan

$$
\begin{aligned}
S_{0} & =\sum_{i=1}^{n} \sum_{j=1}^{n} w_{i j}, \\
S_{1} & =\frac{1}{2} \sum_{i \neq j}\left(w_{i j}+w_{j i}\right)^{2}, \\
S_{2} & =\sum_{k}\left(\sum_{j} w_{k j}+\sum_{i} w_{i k}\right)^{2} .
\end{aligned}
$$

Uji signifikansi Geary's c dilakukan dengan hipotesis sebagai berikut

$$
\begin{aligned}
& H_{0} \text { : tidak terdapat autokorelasi spasial, } \\
& H_{1} \text { : terdapat autokorelasi spasial. }
\end{aligned}
$$

Statistik uji yang digunakan pada pengujian ini adalah

$$
z(c)=\frac{c-1}{\sqrt{\operatorname{Var}(c)}} .
$$

Jika diperoleh nilai $|z(c)|<z_{\alpha / 2}$ maka diambil keputusan tolak $H_{0}$ yang menyatakan bahwa terdapat autokorelasi spasial.

\section{Metode Penelitian}

Data yang digunakan dalam penelitian ini adalah data sekunder kasus malaria di 23 kabupaten/kota di Provinsi Aceh tahun 2017. Data pada penelitian ini didapatkan dari Profil Kesehatan Provinsi Aceh 2017 dan Badan Pusat Statistik (BPS) yaitu Aceh dalam Angka 2018.

\section{Pembahasan}

\subsection{Matriks Pembobot Spasial}

Untuk menentukan adanya autokorelasi spasial, komponen utama yang di perlukan adalah peta lokasi. Peta digunakan untuk menentukan hubungan ketetanggaan antar kabupaten/kota di Provinsi Aceh. Dengan menggunakan metode Queen Contiguity diperoleh matriks pembobot spasial sebagai berikut. 


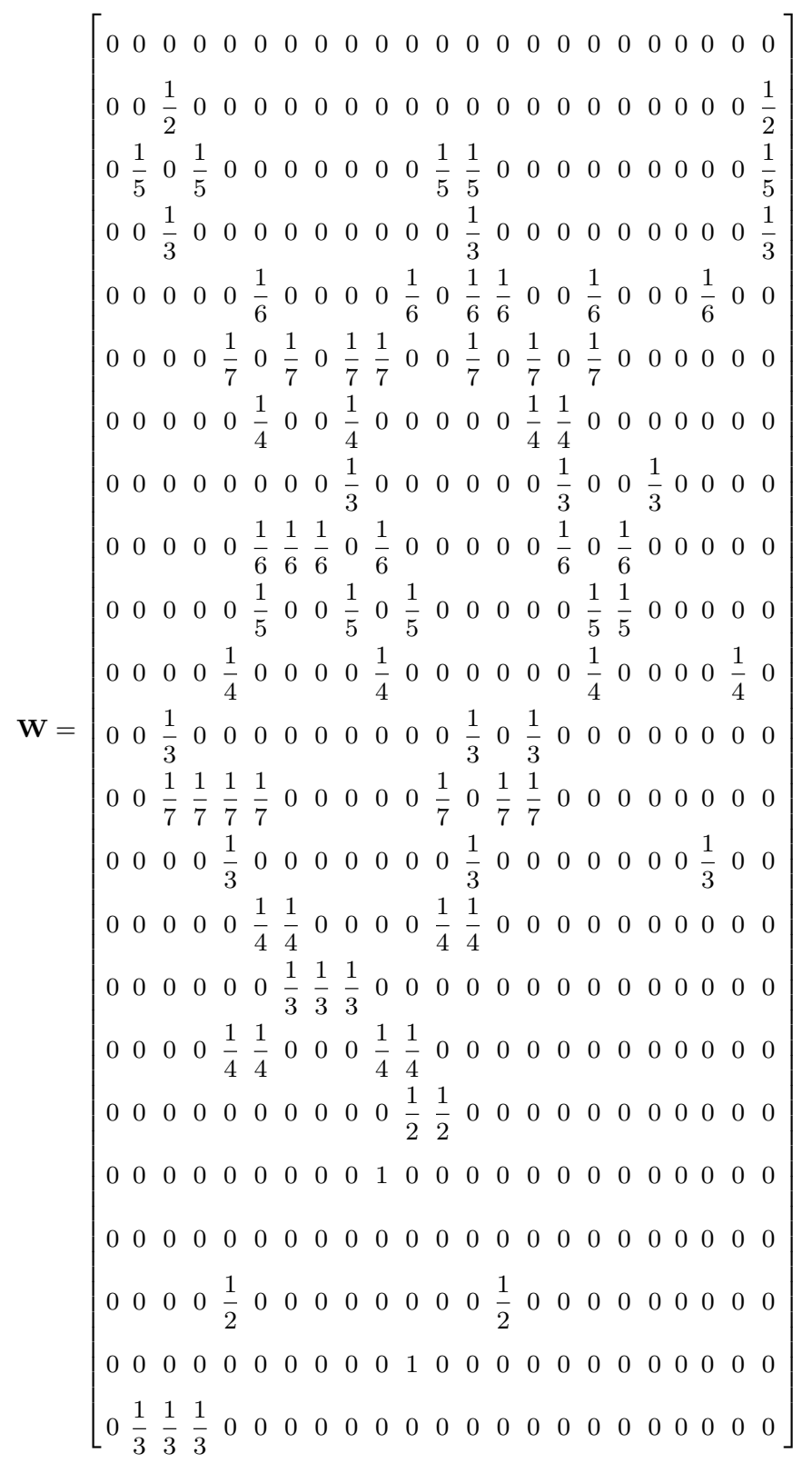


244 Meilina Diniari $d k k$

\subsection{Korelasi Geary's c}

Salah satu metode untuk mengukur autokorelasi spasial adalah Geary's c. Perhitungan koefisien Geary adalah sebagai berikut.

$$
\begin{aligned}
\sum_{i=1}^{n} \sum_{j=1}^{n} w_{i j}\left(Y_{i}-Y_{j}\right)^{2}= & (0(0)+0(83375161)+\cdots+0(83576164))+(0(83375161) \\
& +0(0)+0,5(3240000)+\cdots+0,5(121))+\cdots \\
& +(0(83576164)+0,333(121)+0,333(3279721)+\cdots+0(0)) \\
= & 123722460,7 . \\
\sum_{i=1}^{n}\left(Y_{i}-\bar{Y}\right)^{2}= & \left((9147-1778,26087)^{2}+(16-1778,26087)^{2}+\cdots\right. \\
& \left.+(768-1778,26087)^{2}+(5-1778,26087)^{2}\right) \\
= & (54298316,37+3105563,374+\cdots+1020627,025+3144454,113) \\
= & 118306224,4 .
\end{aligned}
$$

Berdasarkan perhitungan diatas diperoleh

$$
c=\frac{(n-1) \sum_{i=1}^{n} \sum_{j=1}^{n} w_{i j}\left(Y_{i}-Y_{j}\right)^{2}}{2\left(\sum_{i=1}^{n}\left(Y_{i}-\bar{Y}\right)^{2}\right)\left(\sum_{i=1}^{n} \sum_{j=1}^{n} w_{i j}\right)}=\frac{(23-1) 123722460,7}{2(118306224,4)(22)}=0,513794945
$$

Nilai koefisien Geary's $c=0,513794945<E(c)=1$ menunjukkan bahwa terdapat autokorelasi spasial positif yang artinya wilayah yang saling berdekatan memiliki nilai yang sangat mirip. Selanjutnya dilakukan uji signifikansi Geary's c dengan hipotesis:

$$
\begin{aligned}
& H_{0} \text { : tidak terdapat autokorelasi spasial, } \\
& H_{1} \text { : terdapat autokorelasi spasial. }
\end{aligned}
$$

Statistik uji

$$
\begin{aligned}
S_{0}= & \sum_{i=1}^{n} \sum_{j=1}^{n} w_{i j}=(0+0+\cdots+0)+(0+0+0,5+\cdots+0,5)+\cdots \\
& +(0+\cdots+1+\cdots+0)+(0+0,333+0,333+0,333+\cdots+0), \\
= & 22, \\
S_{1}= & \frac{1}{2} \sum_{i \neq j}\left(w_{i j}+w_{j i}\right)^{2} \\
= & \left((0+0)^{2}+(0+0)^{2}+\cdots+(0+0)^{2}\right)+\left((0+0)^{2}+(0,5+0,2)^{2}\right. \\
& \left.+\cdots+(0,5+0,3)^{2}\right)+\cdots+\left((0+0)^{2}+(0,3+0,5)^{2}+\cdots+(0+0)^{2}\right) \\
= & 26,67973271 .
\end{aligned}
$$




$$
\begin{aligned}
S_{2}= & \sum_{k}\left(\sum_{j} w_{k j}+\sum_{i} w_{i k}\right)^{2} \\
= & ((0+0+\cdots+0)+(0+0+\cdots+0))^{2}+((0+0+0,5+\cdots+0,5) \\
& +(0+0+0,2+\cdots+0,3))^{2}+\cdots+((0,33+0,33+\cdots+0) \\
& +(0,5+0,2+\cdots+0))^{2} \\
= & 89,19535268 .
\end{aligned}
$$

Selanjutnya diperoleh

$$
\begin{aligned}
\operatorname{Var}(c) & =\frac{\left(2 S_{1}+S_{2}\right)(n-1)-4 S_{0}^{2}}{s(n+1) S_{0}^{2}} \\
& =\frac{(2(26,67973271)+89,19535268)-\left(4\left(22^{2}\right)\right)}{2(23+1)\left(22^{2}\right)} \\
& =0,068992439 \\
Z(c) & =\frac{c-1}{\sqrt{\operatorname{var}(c)}} \\
& =\frac{0,513794945-1}{\sqrt{0,068992439}} \\
& =-1,851052433 .
\end{aligned}
$$

Karena nilai statistik $|Z(c)|=1,851052433<1,96=Z_{(\alpha / 2)}$, maka dapat disimpulkan bahwa terdapat autokorelasi spasial pada data kasus malaria di Provinsi Aceh pada tahun 2017.

\section{Kesimpulan}

Berdasarkan hasil penelitian diambil kesimpulan sebagai berikut

(1) Berdasarkan perhitungan, nilai koefisien Geary $c=0,513794945<\mathrm{E}(\mathrm{c})=1$ menunjukkan bahwa terdapat autokorelasi spasial positif yang artinya wilayah yang saling berdekatan memiliki nilai yang sangat mirip.

(2) Berdasarkan uji signifikansi koefisien Geary dengan $\alpha=0,05$ disimpulkan bahwa terdapat autokorelasi spasial pada data kasus malaria di Provinsi Aceh pada tahun 2017.

\section{Ucapan Terima kasih}

Penulis mengucapkan terimakasih kepada Dr. Dodi Devianto, Dr. Lyra Yulianti dan Yudiantri Asdi, M.Sc yang telah memberikan masukan dan saran sehingga paper ini dapat diselesaikan dengan baik.

\section{Daftar Pustaka}

[1] Anselin, L. 1998. Spatial Econometrics Methods and Models. Academic Publishers, Dordrecht

[2] Fotheringham A.S., Brunsdon C. dan Charlton M. 2002. Geographically Weighted Regression : The Analysis of Spatially Varying Relationship. John Wiley and Sons LTd, England 
246 Meilina Diniari $d k k$

[3] Gujarati, DN. 2004. Basic Econometrics.McGraw Hill, New York

[4] Lee, J dan D. W. S, Wong. 2001. Statistical Analysis with Arcview GIS. John Willey and Sons Inc, New York

[5] Lesage, JP. 1999. The Theory and Practice of Spatial Econometrics. Departement of Economics, University of Toledo.

[6] Pfeiffer D., Robinson, Stevenson M., Stevens K. dan Rogers D. 2008. Spatial Analysis in Epidemiologi. Oxford University Press, New York 